\title{
Early Cell Envelope Alterations by Tobramycin Associated with its Lethal Action on Pseudomonas aeruginosa
}

\author{
By JANE E. RAULSTON, ${ }^{1}$ and THOMAS C. MONTIE ${ }^{2 *}$ \\ ${ }^{1}$ Department of Biochemistry, University of North Carolina, Chapel Hill, NC 27599-7260, USA \\ ${ }^{2}$ Department of Microbiology, University of Tennessee, Knoxville, TN 37996, USA
}

(Received 29 March 1989; revised 27 June 1989; accepted 7 July 1989)

The immediate activities of the aminoglycoside antibiotic tobramycin were investigated in Pseudomonas aeruginosa PAO1. The lethal action of a low concentration of tobramycin $\left(8 \mu \mathrm{g} \mathrm{ml}^{-1}\right)$ occurred rapidly (1-3 $\left.\mathrm{min}\right)$ and was associated with leakage of certain cellular components into the supernatant. The presence of magnesium at the time of initial exposure protected cells by preventing uptake of tobramycin; however, magnesium addition following a brief exposure did not restore viability. Analyses of supernatant material revealed a rapid 2-fold increase in protein released following tobramycin treatment. A prominent $29 \mathrm{kDa}$ protein, observed by SDS-PAGE in the released material was identified as the periplasmic $\beta$-lactamase. Brief exposure to tobramycin did not result in major morphological damage or cell lysis as observed by transmission electron microscopy, and release of LPS was not a primary event. Although activity at the ribosomal level was observed by 2-3 min, leakage was detected after only $1 \mathrm{~min}$. These data indicate that leakage of cellular components, particularly $\beta$-lactamase, occurs simultaneously, if not prior to inhibition of protein synthesis by tobramycin.

\section{INTRODUCTION}

Several activities are elicited by aminoglycosides in Gram-negative bacteria. Among these pleotrophic effects, it is well established that in Pseudomonas aeruginosa aminoglycosides interfere with protein synthesis at the ribosomal level (Ahmad et al., 1980; Davis et al., 1986; Eagon, 1984; Tanaka et al., 1983), as well as evoking damage to the outer surface (Davis et al., 1986; Eagon, 1984; Hancock et al., 1981; Hancock \& Wong, 1984; Loh et al., 1984; Peterson et al., 1985). While it appears that the site(s) of ribosomal interaction are specific for a given antibiotic (Tanaka et al., 1983), the mechanism of interaction of aminoglycosides with the cell envelope and its relevance in lethal action is less clear.

Studies of the role of outer-membrane proteins in drug activity have suggested that porins are a major route of uptake for several classes of antibiotics (Eagon, 1984; Nakae \& Nakae, 1982; Sawai et al., 1982). By utilizing proteoliposomes and a liposome-swelling technique, Nakae \& Nakae (1982) concluded that aminoglycosides diffuse into Gram-negative bacteria through aqueous pores. Additionally, it has been suggested that a loss of porin in $P$. aeruginosa results in ineffective penetration of polymyxin B (Gilleland \& Farley, 1982). The polymyxins are cationic antibiotics, similar to the aminoglycosides, and are believed to share the same mechanism of activity at the outer surface (Hancock \& Wong, 1984; Moore et al., 1986; Nicas \& Hancock, 1983). High concentrations of divalent cations such as calcium or magnesium have been reported to antagonize the interaction of cationic antibiotics with the cell surface (Abdel-Sayed et al., 1982; Hancock et al., 1981; Loh et al., 1984; Nicas \& Hancock, 1983).

\footnotetext{
Abbreviations: KDO, 2-keto-3-deoxyoctonate (3-deoxy-D-manno-octulonate); MSM, mineral salts medium; TEM, transmission electron microscopy.
} 
Exposure of $P$. aeruginosa to aminoglycosides eventually results in the cell surface becoming permeable to various enzymic, fluorescent and radiolabelled probes (Hancock et al., 1981; Hancock \& Wong, 1984; Loh et al., 1984; Sanders et al., 1987). Permeability-resistant strains have been observed to overproduce outer-membrane protein $\mathrm{H} 1$, which is thought to protect the cell by interaction with antibiotic-binding sites (Nicas \& Hancock, 1980, 1983). In contrast, Bryan et al. (1984) stated that impermeability-type resistance results from conversion of smooth LPS to superficial or deeper rough LPS phenotypes. The negative charges present on LPS have implicated this polysaccharide as a possible site for interaction with the cationic aminoglycosides (Angus et al., 1982; Bryan et al., 1984; Peterson et al., 1985, 1987). Studies utilizing a cationic spin probe have indicated that there are structural changes in LPS during exposure to cationic antibiotics (Peterson et al., 1985, 1987). Peterson et al. (1987) suggested that polymyxin resistance in Escherichia coli results from esterification of the core-lipid A phosphates.

Aminoglycoside antibiotics interfere with toxin A production and eliminate secretion of elastase in P. aeruginosa (OGaard et al., 1986; Warren et al., 1985). Excretion of nucleotides following streptomycin exposure has been reported for some strains of $E$. coli, but is not believed to be associated with lethality (Tzagoloff \& Umbreit, 1963). After extended time periods, aminoglycoside-induced morphological alterations occur, such as the appearance of transient holes in the outer membrane of $P$. aeruginosa (Martin \& Beveridge, 1986), and large blebs in $E$. coli (Tanaka et al., 1983). Davis et al. (1986) have shown that exposure of $E$. coli to streptomycin results in the incorporation of abnormal protein in the cell envelope. They proposed that this altered protein allows increased influx of antibiotic leading to cell death.

Despite all the reported effects elicited by aminoglycosides, the sequence of these events, and their specific reason(s) leading to cell death still remain unclear. The focus of this study was to delineate rapidly occurring envelope damage associated with the lethal action of tobramycin on $P$. aeruginosa PAO1. Damage was investigated by an examination of cellular materials released into the supernatant (versus uptake of an indicator probe), and was compared with the known effect on inhibition of protein synthesis. The influence of individual medium components was carefully assessed, as well as effects on the overall cell morphology. All experiments were done within a very short exposure period, and with a low tobramycin concentration, in order to examine initial activities in a progressive manner.

\section{METHODS}

Bacterial strain and growth conditions. Pseudomonas aeruginosa PAO1 was obtained from A. Kropinski, Queen's University, Kingston, Canada. The stock culture was maintained at $4{ }^{\circ} \mathrm{C}$ in Brain Heart Infusion broth or agar slants (Gibco). Cells were grown in a mineral salts medium (MSM) consisting of $40 \mathrm{mM}-\mathrm{K}_{2} \mathrm{HPO}_{4}, 22 \mathrm{mM}$ $\mathrm{KH}_{2} \mathrm{PO}_{4}, 7.5 \mathrm{mM}-\left(\mathrm{NH}_{4}\right)_{2} \mathrm{SO}_{4}, 0.2 \mathrm{~mm}-\mathrm{MgSO}_{4}$ and $9.3 \mu \mathrm{M}-\mathrm{FeCl}_{3}$ with $0.5 \%(\mathrm{w} / \mathrm{v})$ glucose as the carbon source. Cells grown with glucose, as compared to growth with citrate or succinate, are more susceptible to tobramycin (Raulston et al., 1986) and thus provide a sensitive system for investigation. The cultures were grown at $37^{\circ} \mathrm{C}$ in a gyratory water-bath shaker (175 r.p.m.).

Lethality and radiolabelled-tobramycin uptake studies. Cells were centrifuged at $6000 \mathrm{~g}$ for $15 \mathrm{~min}$ at the onset of exponential growth and resuspended in either fresh MSM (without carbon source), $20 \mathrm{~mm}-$ or $0 \cdot 2 \mathrm{mM}-\mathrm{MgSO}_{4}$, $10 \mathrm{~mm}$-potassium phosphate buffer $\left(\mathrm{pH} \mathrm{7.0)}\right.$ ), or sterile, distilled water at $37^{\circ} \mathrm{C}$. For viability studies, cell suspensions were divided in half; one was exposed to $8 \mu \mathrm{g}$ tobramycin $\mathrm{ml}^{-1}$ (Sigma) and the other served as an unexposed control. After 1, 3 or $5 \mathrm{~min}$, samples were removed for dilution and plating. Additional studies were done with cells suspended in water, treated with $8 \mu \mathrm{g}$ tobramycin $\mathrm{ml}^{-1}$ for $3 \mathrm{~min}$, then immediately supplemented with $20 \mathrm{mM}^{-\mathrm{MgSO}_{4}}$. A soft agar overlay technique was utilized for clean separation of colonies. To quantify uptake $\left[{ }^{3} \mathrm{H}\right]$ tobramycin $\left[8 \mu \mathrm{g} \mathrm{ml}^{-1} ; 1.62 \mu \mathrm{Ci} \mathrm{ml}^{-1}\left(59.9 \mathrm{kBq} \mathrm{ml}^{-1}\right)\right.$; Amersham] was added to cell suspensions at zero-time, and incubated at $37^{\circ} \mathrm{C}$. Samples were removed at intervals of $3 \mathrm{~min}$, filtered and washed once with $10 \mathrm{ml} 10 \mathrm{~mm}$-phosphate buffer (pH 7.0). Filters were then dried, immersed in Bray's scintillation cocktail, and counted.

Protein synthesis. The effect of tobramycin on protein synthesis was measured by following the incorporation of $\mathrm{L}-\left[{ }^{3} \mathrm{H}\right]$ proline into protein. Approximately $5 \times 10^{8} \mathrm{c}$.f.u. $\mathrm{ml}^{-1}$ were centrifuged, resuspended in $10 \mathrm{mM}$-potassium phosphate buffer ( $\mathrm{pH} 7.0$ ) at $37^{\circ} \mathrm{C}$, and divided between two flasks. The assay was begun by addition of $20 \mu \mathrm{M}-\mathrm{L}-$ $\left[{ }^{3} \mathrm{H}\right]$ proline $\left[1 \mu \mathrm{Ci} \mu \mathrm{mol}^{-1}\left(37 \mathrm{kBq} \mu \mathrm{mol}^{-1}\right) ;\right.$ Amersham] to both suspensions at zero-time. Tobramycin $\left(8 \mu \mathrm{g} \mathrm{ml}^{-1}\right)$ was added to one flask $2 \mathrm{~min}$ after proline addition. At intervals of $1 \mathrm{~min}, 0.5 \mathrm{ml}$ samples were added to $0.5 \mathrm{ml}$ icecold $10 \%(\mathrm{w} / \mathrm{v})$ trichloroacetic acid (TCA), and placed on ice for $15 \mathrm{~min}$. Samples were then filtered and washed 
with two $1 \mathrm{ml}$ vols ice-cold $5 \%$ TCA, two $1 \mathrm{ml}$ vols $95 \%$ (v/v) ethanol and $1 \mathrm{ml}$ ether. After drying, each filter was placed into $5 \mathrm{ml}$ of Bray's solution for counting.

Ultraviolet $(U V)$, protein and 2-keto-3-deoxyoctonate $(K D O)$ analyses of supernatant material. Exponential phase cultures were centrifuged, resuspended in $0.1 \mathrm{M}$-potassium phosphate buffer $(\mathrm{pH} 7.0)$ or water at $37^{\circ} \mathrm{C}$, divided between control and treatment flasks, and placed in a shaking water-bath at $37^{\circ} \mathrm{C}$. After addition of $8 \mu \mathrm{g}$ tobramycin $\mathrm{ml}^{-1}$, the suspensions were centrifuged $\left(10000 \mathrm{~g}, 4^{\circ} \mathrm{C}, 5 \mathrm{~min}\right)$ after either 1 or $3 \mathrm{~min}$ exposure. The resulting supernatants were filtered through $0.45 \mu \mathrm{m}$ Millipore filters and either analysed directly or concentrated by lyophilization in small pre-weighed vials. Lyophilized samples were stored at $-70^{\circ} \mathrm{C}$. For spectrophotometric analyses, the supernatant materials were suspended to equivalent concentrations based on dry weight estimates, and scanned in the UV region with a Shimadzu UV-120 dual beam spectrophotometer. The results were expressed as 'difference spectra' between untreated and tobramycin-treated cell supernatants to highlight detection of released components.

The overall protein present in each supernatant sample was quantified by both a modified Lowry method (Markwell et al., 1978) and the Bio-Rad microassay, using BSA (Sigma) as the protein standard. Protein content of washed whole cells was also assessed by both methods since the Lowry method gives a reaction with free aromatic amino acids. The relative amounts of LPS present in the supernatant samples were determined by a modified KDO microassay (Karkhanis et al., 1978). The concentration of each unknown was obtained by interpolation from a standard curve of known concentrations of KDO (Sigma).

Transmission electron microscopy (TEM). Cells were grown to the exponential phase, centrifuged and resuspended in water. Following a $3 \mathrm{~min}$ exposure to $8 \mu \mathrm{g}$ tobramycin $\mathrm{ml}^{-1}$, treated cells (as well as untreated controls) were prepared for TEM according to the procedure described by Martin \& Beveridge (1986). Samples were examined with a Hitachi $\mathrm{H}-600$ transmission electron microscope operating at $100 \mathrm{kV}$, and equipped with a liquid nitrogen cold-trap.

Molecular mass determination. Lyophilized supernatant samples were suspended in a sample buffer according to the method of Laemmli (1970), and heated for $10 \mathrm{~min}$ at $100^{\circ} \mathrm{C}$. Bio-Rad low molecular mass markers were suspended in sample buffer, but not heated. SDS-PAGE of the samples was done in a $10-15 \%(\mathrm{w} / \mathrm{v})$ polyacrylamide gradient (Pharmacia PhastSystem). Following electrophoresis, silver-staining for protein was accomplished by utilization of development technique file \#210 (Pharmacia PhastSystem).

For the analysis of a specifically released protein by gel filtration chromatography, 11 vols of cells were

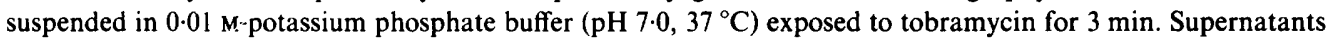
were obtained by centrifugation, filtration and lyophilization as before. Samples were extensively dialysed for 24$48 \mathrm{~h}$ to reduce the buffer salts. This concentrate was passed through a $1.5 \times 50 \mathrm{~cm}$ column of Sephacryl S-200 (Sigma) in a running buffer of $0.01 \mathrm{M}$-potassium phosphate $(\mathrm{pH} 7.5)$ plus $0.02 \%$ sodium azide. Fractions $(1 \mathrm{ml})$ were collected and the absorbance at both 280 and $260 \mathrm{~nm}$ was monitored. A $20 \mathrm{ml}$ void volume was determined using Blue Dextran (Sigma). For comparison, 2-4 mg of standard proteins were eluted from the column. These included bovine albumin (molecular mass $66 \mathrm{kDa}$ ), $\beta$-lactoglobulin $(36.8 \mathrm{kDa}$ ) and cytochrome $c(13 \mathrm{kDa})$ (Sigma)

$\beta$-Lactamase activity. A spectrophotometric assay, using the chromogenic cephalosporin substrate nitrocefin, was done as described by O'Callaghan et al. (1972). Reaction conditions involved incubation at $37^{\circ} \mathrm{C}$ in $50 \mathrm{mM}$ potassium phosphate buffer ( $\mathrm{pH} 7.0$ ), with a substrate concentration of $0.1 \mathrm{mM}$. The increase in absorbance at $482 \mathrm{~nm}$ was monitored, and the specific activity expressed as $\mu$ mols substrate destroyed $\min ^{-1}(\mathrm{mg} \text { protein })^{-1}$. Crude, concentrated supernatants obtained from treated or untreated cells suspended in buffer were analysed directly for enzyme activity after dialysis. Pooled fractions from the Sephacryl S-200 column were concentrated and the enzyme activity was assessed. Additionally, cells were suspended in phosphate buffer, sonicated, centrifuged, and the resultant supernatant was assayed for $\beta$-lactamase activity for comparison.

Statistical analyses. Statistical significance was determined by Student's $t$-test $(P>0.05)$ for those experiments with a sampling size of 25 or greater. For experiments representing the mean of duplicate samples, differences were expressed as a percentage.

\section{RESULTS}

Influence of medium constituents on uptake and lethal action of tobramycin

The protection provided to tobramycin-exposed $P$. aeruginos $a$ PAO1 by MSM, magnesium or phosphate is shown in Table 1. Although physiologically artificial, cells suspended in water were examined for comparison as the most damaging system, containing no protective substances. The majority of cells ( $>50 \%$ ) suspended in phosphate buffer or water were killed by tobramycin within $3 \mathrm{~min}$. The presence of magnesium, alone or in MSM (which contains phosphate buffer), protected cells from the lethal action of tobramycin. Protection required the initial presence of magnesium; later addition of magnesium, following a $3 \mathrm{~min}$ exposure to tobramycin, did not 
Table 1. Immediate bactericidal action of tobramycin toward P. aeruginosa $P A O 1$

Cells were grown in MSM + glucose, centrifuged, resuspended in medium at $37^{\circ} \mathrm{C}$ and treated at zero time with $8 \mu \mathrm{g}$ tobramycin $\mathrm{ml}^{-1}$ where indicated.

\begin{tabular}{|c|c|c|c|}
\hline Medium & $\begin{array}{l}\text { Exposure time } \\
\text { (min) }\end{array}$ & C.f.u. $\mathrm{ml}^{-1}$ & $\begin{array}{c}\text { Lethal } \\
\text { action }(\%)^{*}\end{array}$ \\
\hline MSM & $\begin{array}{l}0 \\
3 \text {, untreated } \\
3 \text {, treated }\end{array}$ & $\begin{array}{l}2 \cdot 1 \times 10^{8} \\
2.1 \times 10^{8} \\
1.5 \times 10^{8}\end{array}$ & $\begin{array}{r}- \\
0 \\
29\end{array}$ \\
\hline $20 \mathrm{~mm}^{-\mathrm{MgSO}_{4}}$ & $\begin{array}{l}0 \\
3 \text {, untreated } \\
3, \text { treated }\end{array}$ & $\begin{array}{l}3.7 \times 10^{8} \\
3.8 \times 10^{8} \\
3.2 \times 10^{8}\end{array}$ & $\begin{array}{r}- \\
0 \\
14\end{array}$ \\
\hline $0.2 \mathrm{mM}^{-\mathrm{MgSO}_{4}}$ & $\begin{array}{l}0 \\
3 \text {, untreated } \\
3 \text {, treated }\end{array}$ & $\begin{array}{l}3.8 \times 10^{8} \\
3.4 \times 10^{8} \\
2.6 \times 10^{8}\end{array}$ & $\begin{array}{l}- \\
11 \\
31\end{array}$ \\
\hline $\begin{array}{l}\text { Potassium phosphate buffer } \\
(10 \mathrm{mM}, \mathrm{pH} 7 \cdot 0)\end{array}$ & $\begin{array}{l}0 \\
3 \text {, untreated } \\
3 \text {, treated }\end{array}$ & $\begin{array}{l}8.7 \times 10^{7} \\
8.8 \times 10^{7} \\
3.0 \times 10^{7}\end{array}$ & $\begin{array}{r}- \\
0 \\
66\end{array}$ \\
\hline Distilled water & $\begin{array}{l}0 \\
3 \text {, untreated } \\
3 \text {, treated }\end{array}$ & $\begin{array}{l}1.5 \times 10^{8} \\
1.2 \times 10^{8} \\
6.5 \times 10^{8}\end{array}$ & $\begin{array}{l}- \\
20 \\
96\end{array}$ \\
\hline
\end{tabular}

* Lethal action was measured as the percentage decrease in c.f.u. $\mathrm{ml}^{-1}$ as compared to the zero-time value. Results represent the mean of duplicate samples, with no individual values exceeding $\pm 6 \%$.

Table 2. Inability of magnesium sulphate to reverse the lethal action of tobramycin

$\begin{array}{lccc}\text { Treatment } & \begin{array}{c}\text { Exposure time } \\ (\mathrm{min})\end{array} & \text { C.f.u. } \mathrm{ml}^{-1} & \begin{array}{c}\text { Lethal } \\ \text { action }(\%)^{*}\end{array} \\ \text { Distilled water } & 0 & 2.8 \times 10^{8} & - \\ & 3 & 2.7 \times 10^{8} & - \\ \text { Tobramycin } & 10 & 2.8 \times 10^{8} & 0 \\ & 0 & 3.3 \times 10^{8} & - \\ \text { Tobramycin and magnesium } \dagger & 3 & 6.0 \times 10^{5} & >99 \\ & 10 & 8.0 \times 10^{4} & >99 \\ & 0 & 3.4 \times 10^{8} & - \\ & 3 & 3.5 \times 10^{5} & >99 \\ & 10 & 6.6 \times 10^{5} & >99\end{array}$

* As Table 1 .

† Magnesium sulphate $(20 \mathrm{~mm})$ was added after $3 \mathrm{~min}$ exposure to $8 \mu \mathrm{g}$ tobramycin $\mathrm{ml}^{-1}$, and incubation was continued for a further $7 \mathrm{~min}$.

restore viability (Table 2). These results demonstrate that lethal damage to the cell is immediate and irreversible.

To show that magnesium antagonizes the initial interaction of tobramycin with cells, the amount of radiolabelled antibiotic taken up and/or tightly associated with cells was assessed. The effect of magnesium was evident. Tobramycin uptake, by $3 \mathrm{~min}$, was 12 times greater $\left[9.8 \times 10^{-4} \mu \mathrm{mol}(\mathrm{mg} \text { protein })^{-1}\right]$ in phosphate buffer in comparison to cells suspended in buffer containing magnesium [8.4 $\times 10^{-5} \mu \mathrm{mol}(\mathrm{mg} \text { protein })^{-1}$; data not shown]. These studies also revealed that with the exception of cells suspended in phosphate buffer, no more than $22 \%$ additional drug was incorporated after the first 3 min exposure. This would suggest that the initial amount of tobramycin taken up is sufficient for lethal damage in these systems. In phosphate buffer, twice as much antibiotic was incorporated by $12 \mathrm{~min}$. The $8 \mu \mathrm{g} \mathrm{ml}^{-1}$ concentration of tobramycin used in these studies is just above the minimal inhibitory concentration (MIC) for P. aeruginosa PAOl grown in both MSM as well as Mueller Hinton medium (Raulston et al., 1986), indicating no added protection by enriched media. 


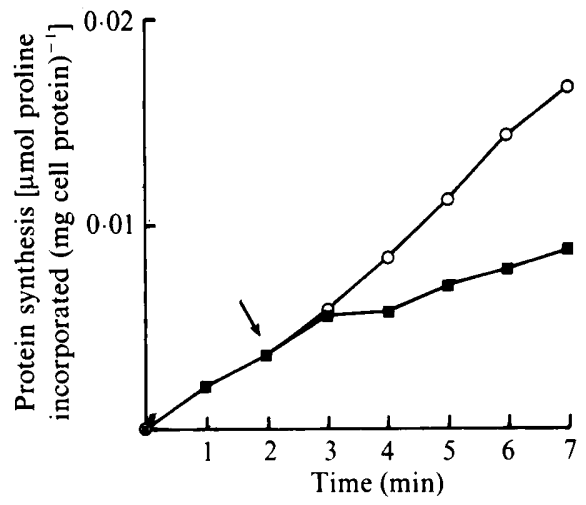

Fig. 1

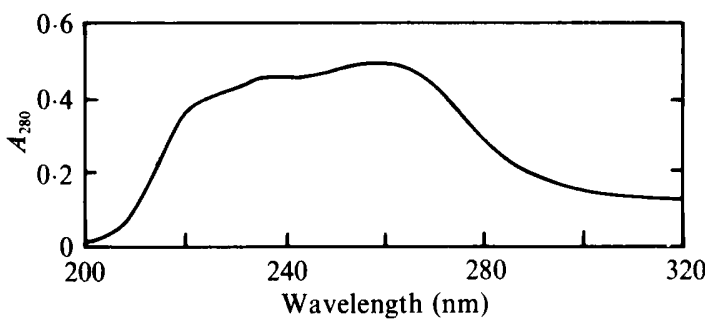

Fig. 2

Fig. 1. Inhibition of protein synthesis by $8 \mu \mathrm{g}$ tobramycin $\mathrm{ml}^{-1}$ in $P$. aeruginosa PAOl. L- $\left[{ }^{3} \mathrm{H}\right] \mathrm{Proline}$ was added at zero-time in both control $(O)$ and tobramycin-treated $(\boldsymbol{D})$ suspensions. Tobramycin was added (arrow) 2 min after proline uptake was initiated. Results represent the mean of duplicate experiments.

Fig. 2. Release of UV-absorbing material from $P$. aeruginosa PAO1 following exposure to $8 \mu \mathrm{g}$ tobramycin $\mathrm{ml}^{-1}$ for $1 \mathrm{~min}$ in phosphate buffer. The trace shown is a representative 'difference spectrum' between untreated and tobramycin-treated supernatant fractions; such experiments were consistently duplicated.

\section{Inhibition of protein synthesis}

The extent of inhibition of protein synthesis was examined under the same, defined conditions utilized for lethal action and envelope-damage studies. The amount of proline incorporated into protein was determined at $1 \mathrm{~min}$ intervals (Fig. 1). Tobramycin (arrow) was added after 2 min of proline uptake. Results show no difference after a 1 min exposure, but approximately $40 \%$ inhibition after exposure for $3 \mathrm{~min}$.

\section{Analysis of cell supernatants for release of cellular components}

The damaging effect of tobramycin on the cell surface was assessed initially by spectrophotometrically examining cell supernatants for material released. The supernatant from cells treated with tobramycin for only $1 \mathrm{~min}$ contained an increased amount of UV-absorbing material compared to the unexposed, control supernatant (Fig. 2). Overnight dialysis of these samples resulted in a loss of some of the UV-absorbing material indicating the presence of small components, possibly amino acids and/or polypeptides, in addition to larger components $(>10$ $12 \mathrm{kDa}$ ). It is important to emphasize that leakage of cellular material could be detected after exposure for $1 \mathrm{~min}$, whereas interference with protein synthesis was difficult to demonstrate at this stage.

Additional spectrophotometric scans were obtained of supernatants derived (i) from cells suspended in distilled water or $20 \mathrm{~mm}$-magnesium (for comparison with phosphate buffer), and (ii) from cells treated with tobramycin for longer than $3 \mathrm{~min}$. Release was more rapid and extensive in cells suspended in water compared to cells suspended in buffer; however, the UVpeak profiles were very similar (data not shown). No leakage was observed from cells suspended in magnesium sulphate. Extended exposure in a buffered environment indicated that following initial leakage, an additional increase of material in the supernatant occurred after exposure for 12 min or more.

Investigations were continued to define the composition of the material released. Since leakage was most extensive in cells suspended in water, this system was initially used to accentuate released components that may have otherwise been difficult to detect. Samples were analysed (i) for LPS by a modified KDO microassay (Karkhanis et al., 1978), and (ii) for protein by both the micro-Bio-Rad and Lowry assays. As shown in Fig. 3, there was a more than 2-fold increase of protein in the supernatant following tobramycin treatment. The amount of protein 


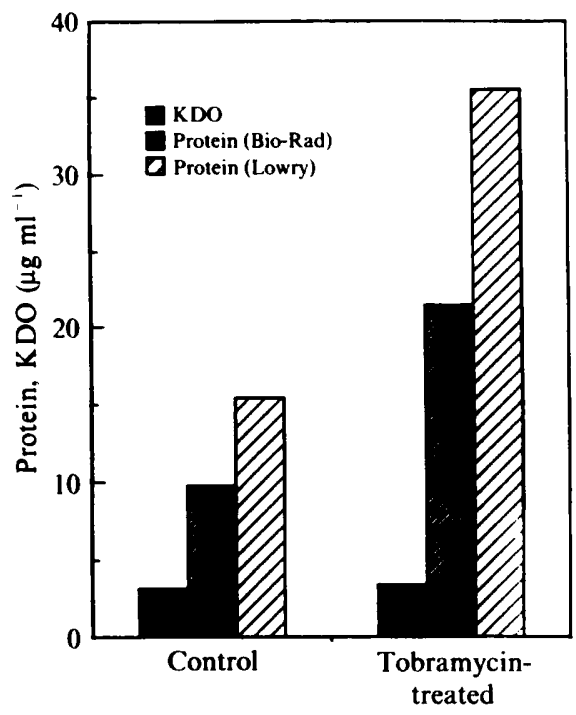

Fig. 3. Direct comparative analysis of $P$. aeruginosa PAO1 supernatants for protein released and for LPS. Cells were suspended in water (at $37^{\circ} \mathrm{C}$ ) and either treated with $8 \mu \mathrm{g}$ tobramycin $\mathrm{ml}^{-1}$ for three min or left untreated. Unconcentrated supernatants were analysed by the micro-Bio-Rad and Lowry protein assays as well as the KDO microassay for LPS. Results represent the mean of duplicate experiments.

was greater by the Lowry versus the micro-Bio-Rad method. Since only the Bio-Rad reaction is specific for peptide bonds, this observation, together with the finding that dialysis of supernatants resulted in a loss of low molecular mass material, strengthened the notion that free amino acids or small peptides were released. We failed to detect an increase in the amount of KDO in the supernatant following brief exposure (Fig. 3): however, an increase was observed by 12 min of treatment (data not shown).

\section{Protein release and lethality}

Since protein is a major component of the material released immediately from cells following exposure to tobramycin, this event was compared with lethal action over time. Cells suspended in buffer were used to show that protein release was not an artefact of suspending cells in water. Fig. 4 clearly illustrates that protein release paralleled the rapid lethal activity of tobramycin. After exposure for only $1 \mathrm{~min}$, the number of c.f.u. was reduced by $39 \%$ and the protein content of the supernatant had increased $1 \cdot 7$-fold.

\section{TEM of cells exposed to tobramycin}

As illustrated in Fig. 5, there were no obvious immediate morphological alterations caused by tobramycin (even in the damaging water-environment), such as excessive outer-membrane blebbing (Tanaka et al., 1983) or the appearance of holes through the surface as has been observed previously (Martin \& Beveridge, 1986). However, on careful examination, the surface features of cells exposed to tobramycin did appear more 'wrinkled' (Fig. $5 b, d$; arrowed) when compared to the surface topology of the untreated control cells. While an association between increased LPS release and bacterial surface blebbing has been reported (Martin \& Beveridge, 1986), we were unable to define a significant increase in the number of blebs per mm of bacterial

Fig. 5. Morphology of $P$. aeruginosa PAO1 before and after tobramycin treatment. Cells were examined by thin-section electron microscopy. (a) Control cells at a magnification of $20000 ;(b)$ cells treated with $8 \mu \mathrm{g}$ tobramycin $\mathrm{ml}^{-1}$ for $3 \mathrm{~min}$, magnification $20000 ;(c)$ as $(a)$ except at a magnification of $100000(\mathrm{bar}, 0 \cdot 1 \mu \mathrm{m}) ;(d)$ as $(b)$ except at a magnification of 100000 . 


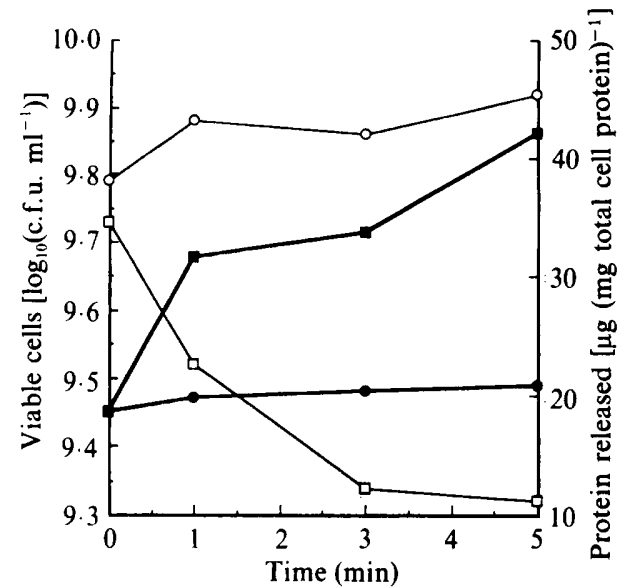

Fig. 4. Release of protein from $P$. aeruginosa $\mathrm{PAO} 1$ associated with the lethal action of tobramycin. Cells were suspended in $0.01 \mathrm{M}$-potassium phosphate buffer $\left(\mathrm{pH} \mathrm{7.0)}\right.$ at $37^{\circ} \mathrm{C}$. Lethal action over time for control $(O)$ and treated $(\square)$ cells was determined by plate counts. Protein release over time for control $(\bullet)$ and treated $(\square)$ cells was determined by Lowry analysis of the concentrated supernatants. Results represent the mean of duplicate experiments.
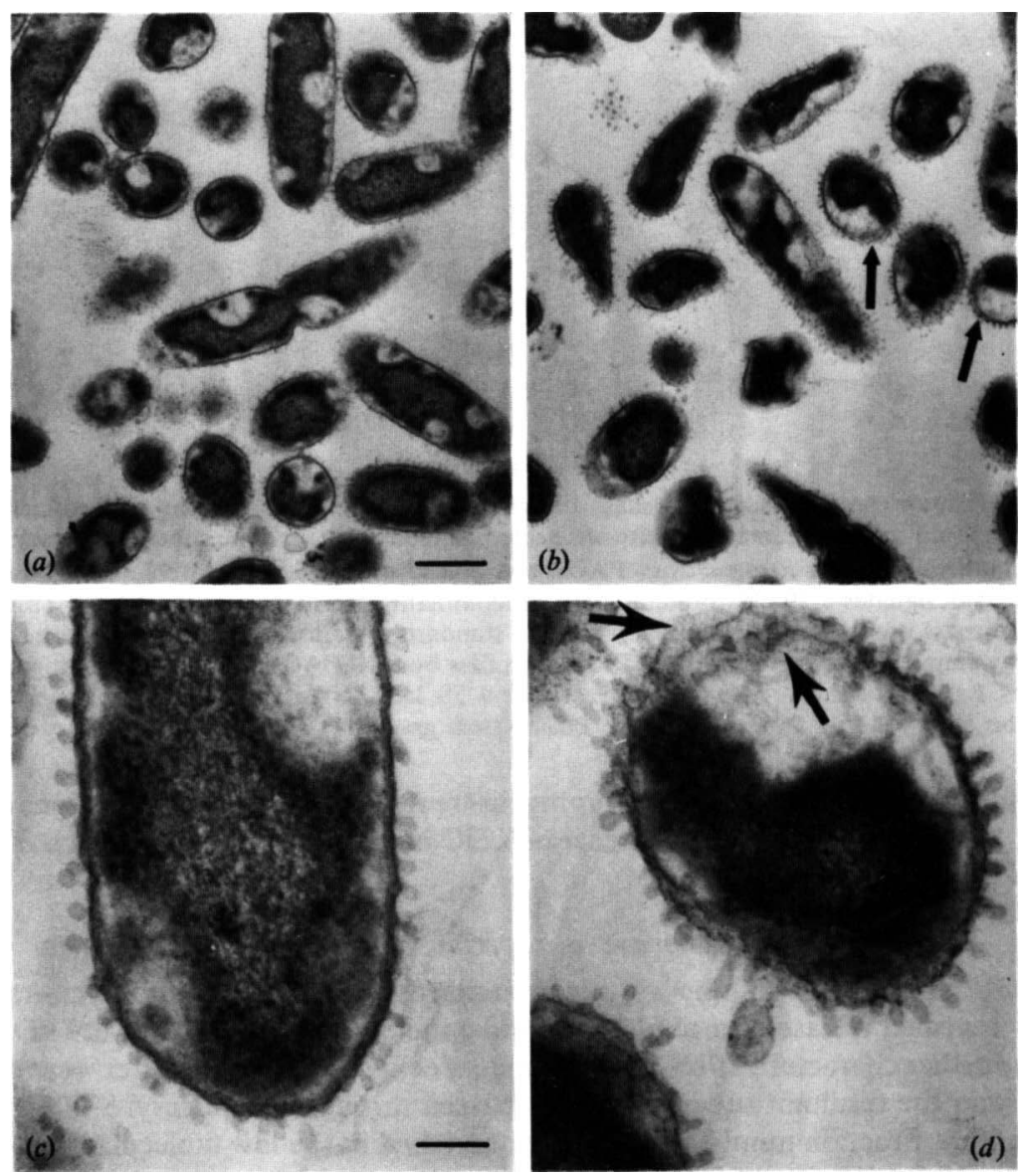


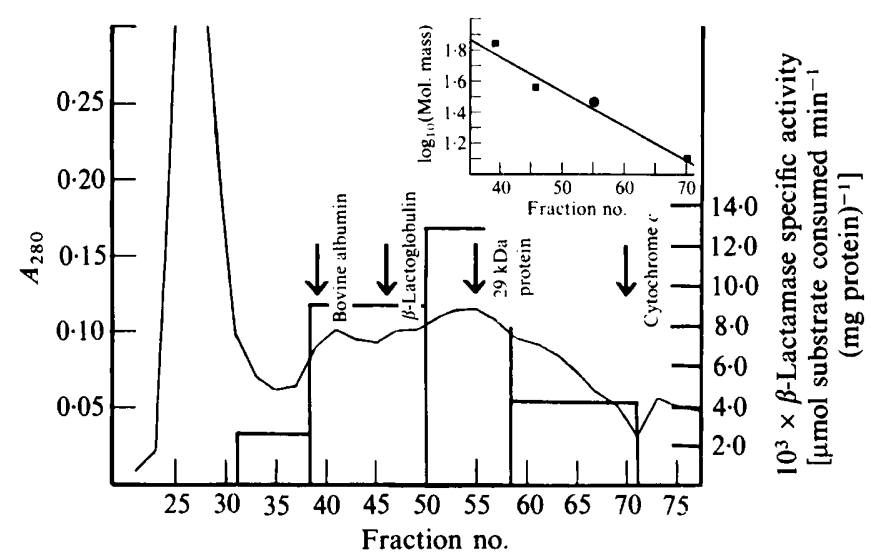

Fig. 6(a)

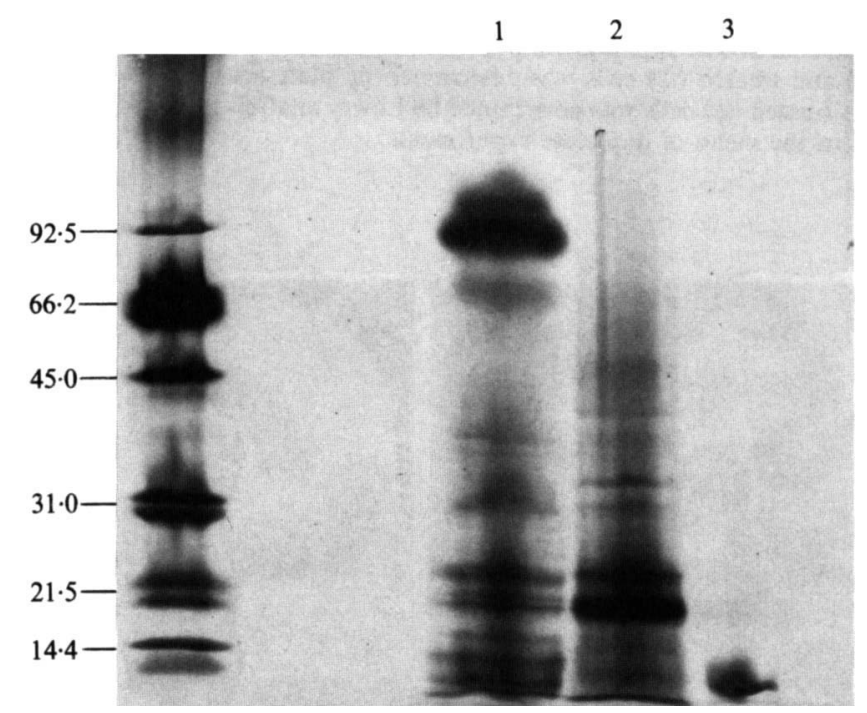

Fig. 6(b)

Fig. 6. (a) Elution profile, molecular mass determination of released protein by Sephacryl S-200 chromatography and $\beta$-lactamase activity of selected, pooled fractions. The concentrated supernatant from tobramycin-treated $P$. aeruginosa PAOl was placed on a $1.5 \times 50 \mathrm{~cm}$ column. The arrow at fraction 55 designates a $29 \mathrm{kDa}$ protein as the predominant species in fractions $50-58$. This relative molecular mass was estimated by comparison with standard proteins (see inset; correlation coefficient $=0.99$ by simple linear regression). (b) Protein profiles by SDS-PAGE and silver-staining of pooled fractions. Lane 1, fractions 38-49; lane 2, fractions 50-58; lane 3, fractions 59-71. Some band 'doublet' formation observed was an artifact of the Phastsystem gradient.

surface profile between untreated and tobramycin-treated cells. These observations support the data in Fig. 3 showing no detectable increase of KDO in the supernatant as a result of short-term tobramycin exposure.

\section{Identification of $\beta$-lactamase as a specific, tobramycin-released protein}

SDS-PAGE and silver staining of supernatant material from tobramycin-treated cells consistently revealed release of a predominant low molecular mass protein $(29 \mathrm{kDa}$; data not shown). For further characterization, litre volumes of cells suspended in buffer were treated with tobramycin and the resultant supernatant was passed through a Sephacryl S-200 gel filtration column (Fig. $6 a$ ). Fraction numbers $50-58$ were enriched in the low molecular mass protein as observed by SDS-PAGE (Fig. $6 b$, lane 2). A small amount of this protein appeared in fraction 
Table 3. Release of $\beta$-lactamase from P. aeruginosa PAOI by exposure to tobramycin

\section{Sample}

Sonicate

Supernatant from untreated cells

Supernatant from tobramycin-treated cells

$$
\begin{aligned}
& \beta \text {-Lactamase activity } \\
& \left(\mu \mathrm{mol} \mathrm{min}-1 \mathrm{ml}^{-1}\right)^{*}
\end{aligned}
$$

Specific activity $\left(\mu \mathrm{mol} \mathrm{min} \mathrm{mg}^{-1} \mathrm{mg}^{-1}\right) \dagger$

$$
\begin{aligned}
& 3.39 \times 10^{-2} \\
& 1.95 \times 10^{-3} \\
& 1.42 \times 10^{-2}
\end{aligned}
$$

Relative activity $(\%)$

6

42

* $\mu \mathrm{mol}$ substrate consumed $\min ^{-1}(\mathrm{ml} \text { sample })^{-1}$ at $37^{\circ} \mathrm{C}, \mathrm{pH} 7 \cdot 0$.

$\dagger \mu$ mol substrate consumed $\min ^{-1}$ (mg protein) ${ }^{-1}$ at $37^{\circ} \mathrm{C}, \mathrm{pH} \mathrm{7.0}$.

numbers 38-49 (Fig. $6 b$, lane 1); however, high molecular mass material was also present. Fraction numbers 59-71 contained very little protein, as did all fractions below 37 . Although the migration of the low molecular mass protein was more rapid in SDS-PAGE, the molecular mass as determined from its mobility on the Sephacryl S-200 column was $29 \mathrm{kDa}$ (Fig. $6 a$ ).

$P$. aeruginosa is known to produce a low basal level of chromosomally encoded, type $1 \mathrm{~d} \beta$ lactamase (Nordstrom \& Sykes, 1974a, b), which has the same substrate profile, electrophoretic mobility and molecular mass as the induced enzyme (Nordstrom \& Sykes, 1974a). The molecular mass of this enzyme is $29 \mathrm{kDa}$. An investigation of $\beta$-lactamase activity in the pooled fractions in Fig. 6 revealed that activity was primarily present in fractions 50-58 which were enriched in the $29 \mathrm{kDa}$ protein. Activity was also detected in fractions $38-49$, but these contained high molecular mass material also. It is possible that a portion of this activity may be contributed by a higher molecular mass $\beta$-lactamase (Poole \& Hancock, 1983) in addition to the $29 \mathrm{kDa}$ protein present. Cell extracts from bacteria lysed by sonic oscillation were assayed for $\beta$ lactamase and this value was taken as $100 \%$ activity (Table 3 ). Relative to this enzyme activity, $42 \%$ activity was present in supernatants following tobramycin treatment whereas only $6 \%$ activity was found in supernatants from unexposed cells.

\section{DISCUSSION}

The mechanism(s) of activity of aminoglycoside antibiotics have been described as multifactorial (Dalhoff, 1987). The focus of this study was the immediate damage to the cell envelope of $P$. aeruginosa PAO1 caused by the aminoglycoside antibiotic tobramycin. Past studies have been done with high concentrations of aminoglycoside, or following exposure periods of $15 \mathrm{~min}$ or more. Under such conditions, separation of primary from secondary drug effects, and attempts to relate these events to lethal action become difficult.

Our approach involved utilization of a consistent, well-defined system in order to assess the degree of interference by inhibitory or competitive substances (Abdel-Sayed et al., 1982; Eagon, 1984; Hancock et al., 1981; Hancock \& Wong, 1984; Loh et al., 1984; Nicas \& Hancock, 1983; Peterson et al., 1985). In support of previous suggestions, magnesium antagonized tobramycin uptake and protection against lethal action. Davis et al. (1956) proposed that aminoglycoside activity begins with slight initial entry of the drug, followed by ribosomal interaction and incorporation of misread protein in the envelope, and finally, increased uptake of additional antibiotic which is responsible for cell death. Examining the protective role of magnesium in more detail, we found that supplementing cells with magnesium immediately following a brief exposure to tobramycin did not restore viability. This suggests that the initial amount of antibiotic taken up is sufficient for irreversible lethal damage and that a later influx of antibiotic is not required. An increase in UV-absorbing compounds was detected in the cell supernatant after only $1 \mathrm{~min}$ of tobramycin treatment. Inhibition of protein synthesis, under the same conditions, was not evident until 2-3 min of exposure indicating that lethal action and release of UV-absorbing compounds occurred at least simultaneously with, if not prior to, damage at the ribosomal level.

Further examination of the composition of released material revealed an immediate increase in protein. Although release of $\mathrm{KDO}$, associated with notable morphological damage has been 
reported (Martin \& Beveridge, 1984), our studies indicate that this is not an immediate event and most likely represents a secondary result of lethal action. Protein release, on the other hand, clearly parallels the lethal action. Quantitative differences in the protein assays, in addition to a loss of UV-absorbing material following dialysis suggested the presence of small polypeptides and/or amino acids. The supernatant material, when examined by TLC and HPLC, was found to contain basic amino acids, indicating their immediate release by tobramycin (data not shown). Since it is known that the membrane potential is involved in the energy-dependent accumulation of aminoglycosides (Bryan \& K wan, 1983), release of basic amino acids, as well as potassium ions (Dubin \& David, 1961), may reflect an effort by exposed cells to stabilize internal charge and maintain the proton electrochemical gradient. Emling \& Höltje (1987) suggested that the membrane potential may increase on initial exposure, leading to influx of additional antibiotic, and ultimately result in efflux of positively charged species. The leakage of other small components following aminoglycoside treatment, such as nucleotides (Roth et al., 1960), has been described; using a firefly luciferase method, we were unable to detect ATP as an immediately released component (data not shown).

A continued investigation as to the nature and origin of released protein revealed one predominant protein (molecular mass $29 \mathrm{kDa}$ ) associated with tobramycin activity. Given that Pseudomonas constitutively produces a $29 \mathrm{kDa}$, chromosomally encoded $\beta$-lactamase (Nordstrom \& Sykes, $1974 a, b$ ) we investigated and subsequently provided strong evidence that tobramycin potentiates a selective release of $\beta$-lactamase. To support this observation, supernatants were assayed for the release of another periplasmic protein, asparaginase (Yellin \& Wriston, 1966); none was released as a consequence of tobramycin exposure. Also, osmotic shock extracts of glucose-grown $P$. aeruginosa PAOl revealed the presence of several low molecular mass proteins, in addition to the $29 \mathrm{kDa}$ protein (data not shown). It is interesting that low levels of aminoglycosides inhibit the excretion (transcription) of some $P$. aeruginosa exoproducts such as protease (OGaard et al., 1986; Warren et al., 1985). It may be that two completely different mechanisms of action are involved depending on the tobramycin concentration and perhaps the time of exposure.

Although $\beta$-lactamase release, as an initial event of aminoglycoside activity has not been previously documented, its release from the periplasmic space has been observed in the presence of other antibiotics. In Pseudomonas, $\beta$-lactamase was released following induction with benzylpenicillin (Nordstrom \& Sykes, 1974a). Amdinocillin and impenem potentiate $\beta$ lactamase release from Gram-negative bacteria prior to induction (Sanders et al., 1987), demonstrating that induction is not necessary for leakage. The specificity reported here agrees well with the observations by Nordstrom \& Sykes (1974a) that $\beta$-lactamase excretion appears to be attributable to an opening in the outer membrane rather than cell lysis. An interesting parallel here might be the lethal action of colicin which causes release of certain periplasmic enzymes presumably by activation of phospholipase A (Suit \& Luria, 1988). Alternatively, $\beta$-lactamase may be actively excreted following interaction of certain regulator compounds with an outermembrane component(s). It is likely that release of this enzyme is not responsible for lethal action, but that it may represent the earliest detectable signal of envelope damage or stress. Since this stimulation of excretion is not restricted to one group of antibiotics, $\beta$-lactamase may best serve as a probe for detection of early surface damage by several compounds.

In summary, although the causal events in the lethal action of aminoglycosides remain unresolved, several key points are implied by this research: (i) the lethal action of tobramycin is immediate and does not require a high dosage or an extended exposure period; (ii) release of LPS, massive cell lysis or major morphological alterations do not appear to be involved in the primary stages of lethal action; (iii) magnesium protects cells if initially present in the environment, but is unable to reverse tobramycin action if supplied immediately after exposure (which suggests that the primary dose is sufficient for permanent damage); (iv) a selective release of $\beta$-lactamase probably signals initial outer-membrane damage; and (v) the release of other small components, such as basic amino acids, may reflect chemiosmotic imbalances. Future studies on the basis for release of these charged compounds may provide some insight into the mechanism of lethal action. 
We wish to thank Jerry K. Williams, Jr, and Linda Summitt for their expert technical assistance. We also thank Priscilla B. Wyrick for a critical reading of the manuscript. This work was supported in part by a research trainee award to J. E. Raulston from a training grant, National Institute of Allergy and Infectious Diseases.

\section{REFERENCES}

AbDel-Sayed, S., Gonzalez, M. \& Eagon, R. (1982). The role of the outer membrane of Pseudomonas aeruginosa in the uptake of aminoglycoside antibiotics. Journal of Antimicrobial Chemotherapy 10, 173183.

Ahmad, M. H., Rechenmacher, A. \& Bock, A. (1980). Interaction between aminoglycoside uptake and ribosomal resistance mutations. Antimicrobial Agents and Chemotherapy 18, 798-806.

angus, B., Carey, A. M., Caron, D. A., Kropinski, A. M. B. \& Hancock, R. E. W. (1982). Outer membrane permeability in Pseudomonas aeruginosa: comparison of a wild-type with an antibiotic supersusceptible mutant. Antimicrobial Agents and Chemotherapy 21, 299-309.

BRYAN, L. E. \& KWAN, S. (1983). Roles of ribosomal binding, membrane potential, and electron transport in bacterial uptake of streptomycin and gentamicin. Antimicrobial Agents and Chemotherapy 26, 835845.

Bryan, L. E., O'Hara, K. \& Wong, S. (1984). Lipopolysaccharide changes in impermeability-type aminoglycoside resistance in Pseudomonas aeruginosa. Antimicrobial Agents and Chemotherapy 26, 250255.

DALHOFF, A. (1987). Pleotropic actions of aminoglycosides. Antibiotics and Chemotherapy 39, 182-204.

Davis, B. D., Chen, L. \& TAl, P. C. (1986). Misread protein creates membrane channels: an essential step in the bactericidal action of the aminoglycosides. Proceedings of the National Academy of Sciences of the United States of America 83, 6164-6168.

Dubin, D. T. \& Davis, B. D. (1961). The effect of streptomycin on potassium flux in Escherichia coli. Biochimica et biophysica acta 52, 400-402.

EAGON. R. G. (1984). The resistance characteristics of Pseudomonas. Developments in Industrial Microbiology 25, 337-348.

EMLing, F. \& HöltJE, J. V. (1987). Autostimulation of dihydrostreptomycin uptake in Bacillus subtilis. Journal of General Microbiology 133, 3495-3504.

Gilleland, H. E., JR \& Farley, L. B. (1982). Adaptive resistance to polymyxin in Pseudomonas aeruginosa due to an outer membrane impermeability mechanism. Canadian Journal of Microbiology 28, 830-840.

HaNCOCK, R. E. W. \& Wong, G. W. (1984). Compounds which increase the permeability of the Pseudomonas aeruginosa outer membrane. Antimicrobial Agents and Chemotherapy 26, 48-52.

Hancock, R. E. W., Raffle, V. J. \& Nicas, T. I. (1981). Involvement of the outer membrane in gentamicin and streptomycin uptake and killing in Pseudomonas aeruginosa. Antimicrobial Agents and Chemotherapy 19, 777-785.

Karkhanis, Y. O., Zeltrier, R. Z., Jackson, J. J. \& CARLO, O. J. (1978). A new and improved microassay to determine 2-keto-3-deoxyoctonate in lipopolysaccharide of Gram-negative bacteria. Analytical Biochemistry 85, 595-601.
LAEMMLI, U. K. (1970). Cleavage of structural proteins during the assembly of the head of bacteriophage T4. Nature, London 227,680-685.

Loh, B., GraNT, C. \& HaNCock, R. E. W. (1984). Use of fluorescent probe $1-\mathrm{N}$-phenylnaphthylamine to study the interactions of aminoglycoside antibiotics with the outer membrane of Pseudomonas aeruginosa. Antimicrobial Agents and Chemotherapy 26, 546551 .

Markwell, M. A. K., HaAs, S. M., Birber, L. L. \& TOLBERT, H. E. (1978). A modification of the Lowry procedure to simplify protein determination in membrane and lipoprotein samples. Analytical Biochemistry 87, 206-210.

MARTIN N. L. \& BeVERIDGe, T. J. (1986). Gentamicin interaction with Pseudomonas aeruginosa cell envelope. Antimicrobial Agents and Chemotherapy 29, 1079-1087.

MOORe, R. A., Bates, N. C. \& Hancock, R. E. W. (1986). Interaction of polycationic antibiotics with Pseudomonas aeruginosa lipopolysaccharide and lipid A studies by using dansyl polymyxin. Antimicrobial Agents and Chemotherapy 29, 496-500.

NAKAE, R. \& NAKAE, T. (1972). Diffusion of aminoglycoside antibiotics across the outer membrane of Escherichia coli. Antimicrobial Agents and Chemotherapy 22, 554-559.

NiCAS, T. I. \& HANCOCK, R. E. W. (1980), Outer membrane protein $\mathrm{Hl}$ of Pseudomonas aeruginosa: involvement in adaptive and mutational resistance to ethylenediaminetetraacetate, polymixin $\mathrm{B}$, and gentamicin. Journal of Bacteriology 143, 872-878.

NiCAS, T. I. \& HaNCOCK, R. E. W. (1983). Alteration of susceptibility to EDTA, polymyxin B and gentamicin in Pseudomonas aeruginosa by divalent cation regulation of outer membrane protein $\mathrm{H} 1$. Journal of General Microbiology 129, 509-517.

NORSDSTROM, K. \& SYKES, R. B. (1974a). Effects of sublethal concentrations of benzylpenicillin on Pseudomonas aeruginosa. Antimicrobial Agents and Chemotherapy 6, 741-746.

NORDSTROM, K. \& SYXES, R. B. (1974b). Induction kinetics of $\beta$-lactamase biosynthesis in Pseudomonas aeruginosa. Antimicrobial Agents and Chemotherapy 6, 734-740.

O'Callaghan, G. H., Morris, A., Kirby, S. M. \& SHINGLER, A. H. (1972). Novel method for detection of $\beta$-lactamase by using a chromogenic cephalosporin substrate. Antimicrobial Agents and Chemotherapy 1, 283-288.

OGaARd, A. R., Bjoro, K., BuKholm, G. \& Berdal, B. P. (1986). Pseudomonas aeruginosa virulence factors: modifications by subinhibitory concentrations of carbenicillin or gentamicin. Acta pathologica. microbiologica et immunologica scandinavica B94, 6368.

Peterson, A. A., Hancock, R. E. W. \& McGroarty, E. J. (1985). Binding of polycationic antibiotics and polyamines to lipopolysaccharides of Pseudomonas aeruginosa. Journal of Bacteriology 164, 1256-1261. 
Peterson, A., Fesik, S. \& McGroarty, E. (1987). Decreased binding of antibiotics to lipopolysaccharides from polymyxin-resistant strains of Escherichia coli and Salmonella typhimurium. Antimicrobial Agents and Chemotherapy 31, 230-237.

PoOLE, K. \& HANCOCK, R. E. W. (1983). Secretion of alkaline phosphatase and phospholipase $\mathrm{C}$ in $\mathrm{Pseu}$ domonas aeruginosa is specific and does not involve an increase in outer membrane permeability. FEMS Microbiology Letters 16, 25-29.

Raulston, J., Woolf, S. \& Montie, T. C. (1986). Studies on low level aminoglycoside resistance in various Pseudomonas aeruginosa isolates. Abstracts of Annual Meeting, ASM \# A-121, p. 21.

Roth, H., Amos, H. \& Davis, B. D. (1960). Purine nucleotide excretion by Escherichia coli in the presence of streptomycin. Biochimica et biophysica acta 37, 398-405.

SANDers, C. C., SANDers, W. E., JR, Goering, J. V. \& MCCLOSKY, R. V. (1987). Leakage of $\beta$-lactamase: a second mechanism for antibiotic potentiation by amdinocillin. Antimicrobial Agents and Chemotherapy 31, 1164-1168.

Sawai, T., Hiruma, H., Kawana, N., Kaneko, M., TANIYASU, F. \& INAMI, A. (1982). Outer membrane permeation of $\beta$-lactam antibiotics in Escherichia coli, Proteus mirabilis, and Enterobacter cloacae. Antimicrobial Agents and Chemotherapy 22, 585-592.

SUIT, J. L. \& LURIA, S. E. (1988). Expression of kil gene of ColEl plasmid of Escherichia coli Kil' mutants causes release of periplasmic enzymes and of calcium without cell death. Journal of Bacteriology 170, 4963-4966.

TABer, H. W., Mueller, J. P., Mueller, D. F. \& ARRow, A. S. (1987). Bacterial uptake of aminoglycoside antibiotics. Microbiology Reviews 51, 439-457.

Tanaka, N., Matsunga, K., Hirata, A., Matsuhisa, Y. \& Nishimusa, T. (1983). Mechanism of action of habekacin, a novel amino acid-containing aminoglycoside antibiotic. Antimicrobial Agents and Chemotherapy 24, 797-802.

TZAGOLOFF, H. \& UMBREIT, W. W. (1963). Influence of streptomycin on nucleotide excretion in Escherichia coli. Journal of Bacteriology 85, 49-52.

WARREN, R. L., BAKER, N. R., JOHNSON, J. \& Stapleton, M. J. (1985). Selective inhibition of the accumulation of extracellular proteases of Pseudomonas aeruginosa by gentamicin and tobramycin. Antimicrobial Agents and Chemotherapy 27, 468-472.

Yellin, T. \& WRISTON, J. (1966). Purification and properties of guinea pig asparaginase Biochemistry $\mathbf{5}$, 1605-1612. 